\title{
A study on the Self-help Groups of Women and its Contribution to their Socio-economic development in Khordha district, Odisha
}

\author{
Miss Subhashree Mishra*, Dr. H. N. Atibudhi ${ }^{* *}$ \\ * PG Scholar, Deartment of Economics, Institute of Agricultural Sciences, SOADU \\ ${ }^{* *}$ HOD, Department of Economics, Faculty of Institute of Agricultural Sciences, SOADU \\ DOI: 10.29322/IJSRP.10.11.2020.p10729 \\ http://dx.doi.org/10.29322/IJSRP.10.11.2020.p10729
}

\begin{abstract}
Women are a vital part of any society. Over the year, there is a gradual realization of the key role of women and her contribution to the family income and employment is increasing as a result of women empowerment in the country. The World Bank (2001) has suggested that empowerment of women should be key aspect of all social development programs. For ages women in rural India have not received much attention and recognition. They were engaged in domestic work and some other supportive work in the family sector. The term "Empowerment" was introduced at Nairobi, Kenya during International Women Conference in 1985. Women empowerment has many dimensions i.e. social empowerment, economic empowerment, cultural empowerment, legal empowerment and political empowerment.
\end{abstract}

Index Terms- women social empowerment, SHGs, employment generation.

\section{INTRODUCTION}

$\mathrm{W}$ omen are a vital part of any society. "There is no chance for the welfare of the world unless the condition of women is improved"- Swami Vivekananda. Women's development has always been a topic of serious concern in the society and is much debated in recent times. The Constitution of India ensures rights of equality, liberty and dignity to both women and men but in a highly male dominated patriarchal society women are hardly given their share of rights. The Government of India made several efforts for empowerment of women. It introduced the National Policy for Empowerment of Women in 2001 with the goal of empowering women as an agent of socio-economic changes and development. The Department for Women and Child Development was established in the year 1985 as the national machinery for advancement of women and keeping in view the increasing significance of women empowerment and later it was converted into a full-fledged ministry in 2006. Similarly, on the eve of International Women's day on $8^{\text {th }}$ March 2010 the National Mission of Empowerment of Women was launched by the Government of India for all-round development of women.

The origin of SHGs is the brainchild of Grameen Bank of Bangladesh, which was founded by Prof. Mohammed Yunus. Self-help Groups were formed in 1976. He establish Grameen Bank of Bangladesh in the year 1975, to provide micro-finance to rural women and pioneering the concepts of microcredit and microfinance. These loans are given to entrepreneurs too poor to qualify for traditional bank loans. Prof. Yunus was awarded the Nobel Prize in 2006 for his contribution to development. In India, National Bank for Agricultural and Rural Development (NABARD) initiated the starting of the WSHGs (Women Self-help Groups) in 1986-87. But the real effort was taken after 1991-92 with the linkage of Self-help Groups with the banks. Started with 225 Groups in 1992. IN 1993 Reserve bank of India is also allowed Self-help Groups to open saving accounts in bank facility of availing bank services. According to a report from 2006, NABARD estimates that there are 2.2 million Selfhelp Groups in India, representing 33 million member, that have taken loans from banks under its linkage program. In Odisha the total number of Self-Help Groups are 4,29,199.

On 8th March 2001 marked the launch of 'Mission Shakti', an initiative by the Hon'ble Chief Minister Naveen Patnaik of Odisha to empower women across the state. The Odisha government has cleared a proposal for a separate Mission Shakti department that would exclusively work for around 70 lakh rural women associated with nearly six lakh women self-help groups (WSHGs) created under the Mission Shakti movement and now 6 million of Mission Shakti are working. It is a collective approach to combat rural poverty, unjust social relationship and gender inequality and promote development. Empowering women is not just for meeting their economic needs but also more holistic social development. Therefore the present study "A study on the Self-help Groups of Women and its Contribution to their Socio-economic development in Khordha district, Odisha" is undertaken with this specific objectives.

\section{OBJECTIVES}

1. To study the Socio-economic profile of SHG members.

2. To study the contribution of SHGs on additional employment generation of members.

\section{METHODOLOGY}

This chapter is devoted to present the methodological details adopted for fulfilment of the objectives of the study and it 
deals with the description of the study area, sampling design of the study and analytical tools employed. Thus, this chapter provide an insight into the conceptual framework for research design. Various phases of methodology used to carry out the present study are discussed under the following broad headings;

3.1. Description of study area

3.2. Sampling design and collection of data

\section{Description of study area}

Odisha a state on the eastern coast of India, is divided into 30 administrative geographical units called districts. It is the 8th largest state by area, and the 11th largest by population. The state has the third largest population of Scheduled Tribes in India. Khordha district is one of them. Khordha is one of the new districts carved out of the former Puri District on 1st April, 1993. The other new district carved out of Puri was Nayagarh. In the year 2000, the district's name was changed from Khurda to Khordha.

It is the most urbanized of all the districts of Odisha. Khordha is the 6th smallest district in terms of size and $5^{\text {th }}$ biggest in terms of population. The district is divided in to 2 subdivisions, namely Bhubaneswar and Khordha which are further subdivided in to 10 blocks such as Bhubaneswar, Jatni, Balipatna, Balianta, Khordha, Bolagarh, Begunia, Tangi, Banpur and Chilika. The district headquarter is connected to all the block headquarters and important towns by all-weather roads.

\begin{tabular}{|l|l|l|}
\hline $\begin{array}{l}\text { Sl. } \\
\text { No. }\end{array}$ & Particulars & Population \\
\hline
\end{tabular}

\begin{tabular}{|c|c|c|}
\hline 1 & Total Population & $22,551,673$ \\
\hline 2 & Male Population & $11,67,137$ \\
\hline 3 & Female Population & $10,84,536$ \\
\hline 4 & $\begin{array}{ll}\text { Child } & \text { Population(0-6 } \\
\text { year age) }\end{array}$ & $2,37,394$ \\
\hline 5 & Density of Population & 800 sq. km \\
\hline 6 & Sex Ratio & $\begin{array}{l}\text { 929 Females per } 1000 \\
\text { Males }\end{array}$ \\
\hline 7 & $\begin{array}{l}\text { Total Number of } \\
\text { Household }\end{array}$ & $4,94,212$ \\
\hline 8 & $\begin{array}{l}\begin{array}{l}\text { Number } \\
\text { Household }\end{array} \\
\text { of }\end{array}$ & $2,47,304$ \\
\hline 9 & $\begin{array}{l}\text { Number of Urban } \\
\text { Household }\end{array}$ & $2,46,908$ \\
\hline 10 & Main workers & $6,32,625$ \\
\hline 11 & Marginal Workers & $1,59,568$ \\
\hline 12 & Literacy Rate & $86.9 \%$ \\
\hline 13 & Literacy Rate (Rural) & $83 \%$ \\
\hline 14 & Literacy Rate (Urban) & $91 \%$ \\
\hline 15 & Banks & 50 \\
\hline 16 & Hospital & 91 \\
\hline 17 & Assembly Constituency & 8 \\
\hline
\end{tabular}

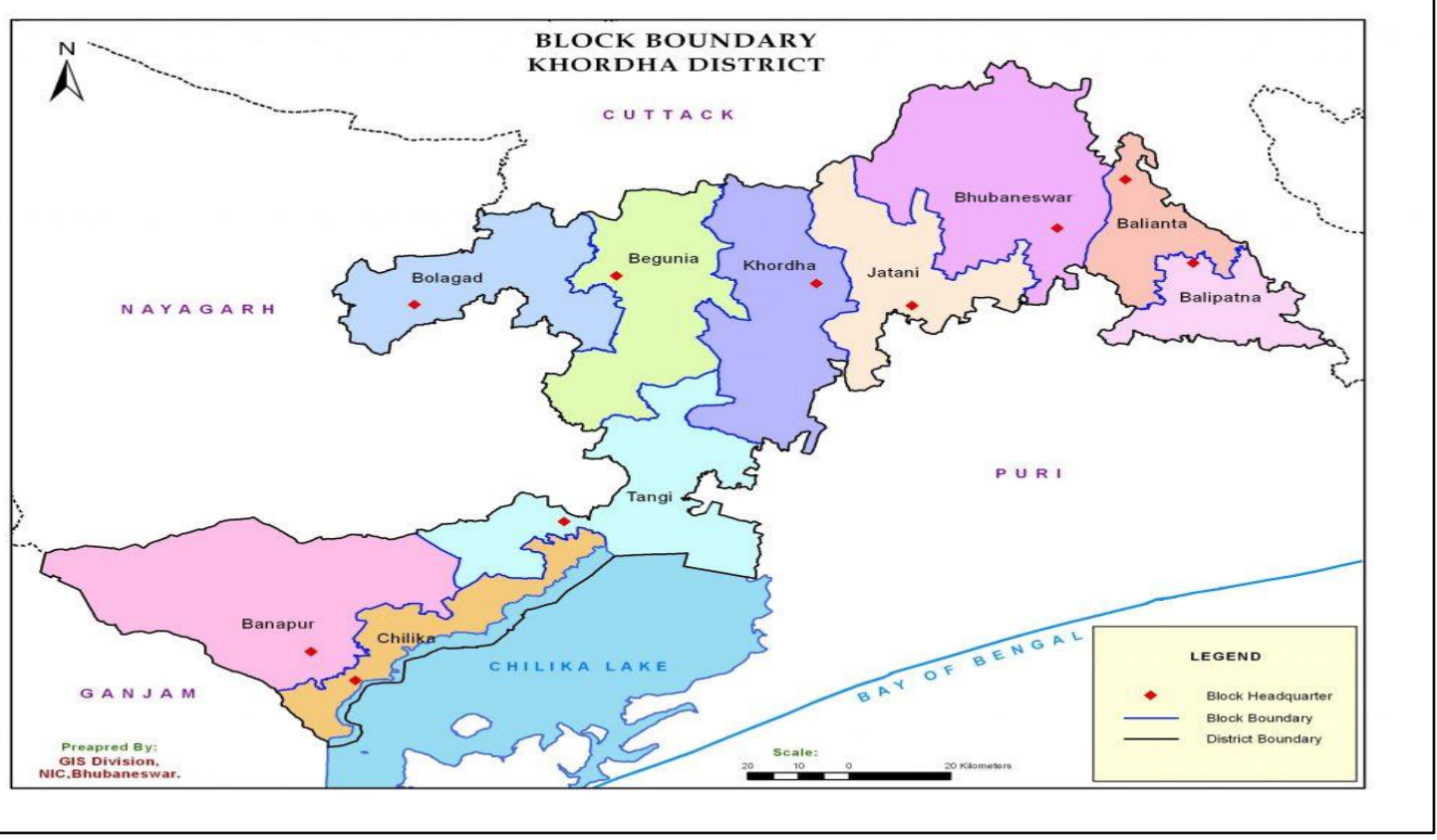

\section{SAMPLING DESIGN AND COLLECTION OF DATA}

The present study is under taken in the Khordha District Odisha purposively because of the convenience of the researcher for the collection of relevant data. The secondary data regarding the district, number of Self-help Group, effective SHGs. Sourced from the DRDA (District Rural Development Agency) office.
After obtaining the information on the effective self-help groups, 8 effective Self-help Groups were randomly selected from a list of 902 Self-help Groups.

Stratified random sampling were adopted for the selection of Self-help Groups. The primary data were collected by interviewing all the members from the 8 self-help groups. A total number of 80,10 each respondents from the SHGs. Where 
interview as per the prepared schedule. The data was collected by 5 round of interview for devoting adequate time each objective.

\section{RESULTS AND DISCUSSION}

In this chapter, the field data and secondary data collected from different sources were analysed and results obtained are presented in accordance with the objectives of the study.

4.1 Socio-economic characteristics of respondents 4.1.1 Number of Self-help Groups in Khordha District

\begin{tabular}{|c|c|c|c|}
\hline \multirow[t]{2}{*}{ Area (under ICDS project) } & \multicolumn{3}{|l|}{ SHGs } \\
\hline & Exiting SHG & New SHG & Total \\
\hline BMC 1 & 549 & 882 & 1,431 \\
\hline BMC 2 & 328 & 490 & 818 \\
\hline BMC 3 & 702 & 961 & 1,663 \\
\hline BBSR (R) & 918 & 958 & 1,876 \\
\hline Balianta & 1320 & 826 & 2,146 \\
\hline Balipatna & 1061 & 684 & 1,745 \\
\hline Jatni & 707 & 1103 & 1,810 \\
\hline Khordha & 902 & 1346 & 2,248 \\
\hline Begunia & 2003 & 951 & 2,954 \\
\hline Bolagard & 1059 & 1084 & 2,143 \\
\hline Tangi & 1981 & 831 & 2,812 \\
\hline Chilika & 1745 & 865 & 2,610 \\
\hline Banapur & 798 & 1278 & 2,076 \\
\hline TOTAL & 14,073 & 12,259 & 26,332 \\
\hline
\end{tabular}

Source: DRDA office

Note: ICDS (Integrated Child Development Services)

The district having 10 blocks with the Bhubaneswar Municipal Corporation (BMC) with a total of 26,332 Self-help Groups. Khordha block accounts for 2,248 Self-Help Groups, out of which 902 are existing SHGs and 1046 are new Self-help Groups. Highest number of SHGs i.e. 2954 exit in Begunia block followed by Tangi and Chillika blocks with 2812 and 2610 respectively.

\subsubsection{Profile of selected SHG groups:}

\begin{tabular}{|l|l|l|l|l|l|l|}
\hline $\begin{array}{l}\text { Sl. } \\
\text { No. }\end{array}$ & $\begin{array}{l}\text { Name of the } \\
\text { Group }\end{array}$ & Village & $\begin{array}{l}\text { No. of } \\
\text { members }\end{array}$ & $\begin{array}{l}\text { Age of } \\
\text { Group }\end{array}$ & $\begin{array}{l}\text { Year of } \\
\text { Establishment }\end{array}$ & Types of Activity \\
\hline 1 & Laxmi SHG & $\begin{array}{l}\text { Khordha town } \\
\text { (Uppersahi) }\end{array}$ & 10 & 13 & 2007 & $\begin{array}{l}\text { Badi \& Masala Badi } \\
\text { making }\end{array}$ \\
\hline 2 & $\begin{array}{l}\text { Maa Bhagabati } \\
\text { SHG }\end{array}$ & Pubusahi & 10 & 4 & 2017 & Fish cultivation \\
\hline 3 & $\begin{array}{l}\text { Gruha laxmi } \\
\text { SHG }\end{array}$ & Diwansahi & 10 & 14 & 2006 & $\begin{array}{l}\text { Badi, Pampad, Arisha } \\
\text { Pitha making, give } \\
\text { training of Tailoring }\end{array}$ \\
\hline 4 & $\begin{array}{l}\text { Padmalaya } \\
\text { SHG }\end{array}$ & Gurujanga & 10 & 2 & 2019 & $\begin{array}{l}\text { Pampad, Badi, School } \\
\text { Bag }\end{array}$ \\
\hline
\end{tabular}




\begin{tabular}{|l|l|l|l|l|l|l|}
\hline 5 & $\begin{array}{l}\text { Baba } \\
\text { kapileswar } \\
\text { SHG }\end{array}$ & Keranga & 10 & 12 & 2008 & THR Chatua \\
\hline 6 & Kasturi SHG & Housing board & 10 & 4 & 2017 & $\begin{array}{l}\text { Badi, Arisha Pitha and } \\
\text { Tailoring }\end{array}$ \\
\hline 7 & Ahamodi SHG & Keranga & 10 & 9 & 2011 & $\begin{array}{l}\text { Sanitation work for } \\
\text { Govt. in Schools, } \\
\text { School MDM }\end{array}$ \\
\hline 8 & Jogamaya SHG & Nabinabag & 10 & 6 & 2014 & Badi making, Tailoring \\
\hline
\end{tabular}

Source: Primary Data

THR: Take Home Ration, MDM: Mid-day Meal

Table 4.1.2 shows the selected eight Self-help Groups for our analysis purpose. These self-help Group are involved in different type of activities like, Badi Making, Masala badi Making, Pampad, Arisha pitha Making, THR Chatua, Nimki Making, School MDM etc. each Self-help group having 10 members.

\section{Period of Functioning SHG:}

Table 4.1.3: Classification of Self-help Groups as per years of establishment

\begin{tabular}{|l|l|l|l|}
\hline Sl. No. & Category & Frequency & Percentage \\
\hline 1 & Less than 3Year & 1 & 12.50 \\
\hline 2 & 3year- 5year & 2 & 25.00 \\
\hline 3 & 5Year-10year & 2 & 25.00 \\
\hline 4 & More than 10year & 3 & 37.50 \\
\hline Total & $\mathbf{8}$ & $\mathbf{1 0 0 . 0 0}$ \\
\hline
\end{tabular}

Source: Primary data

The above Table shows that on the total 8 Self-help Groups 3 (i.e. 37.5 per cent) is more than 10 years of age, 2 SHGs (i.e25 per cent) groups is 3-5 year, 2 SHGs (i.e. 25 per cent) group is5-10 year, 1 SHG (i.e. 12.5 per cent) group is less than 3 year.

\subsubsection{Group Meeting:}

According to guideline of SHG the SHGs should be conduct regular meetings to discuss various issues relating to the group. Economic and social issues like collection and management of credit flow among the members, training problems of SHGs, marketing of the product form part of the agenda of meeting of SHGs.

Table 4.1.4: Classification of SHGs on the basis of Group meetings

\begin{tabular}{|l|l|l|l|}
\hline Sl. No. & Group Meeting & Frequency & Percentage \\
\hline 1 & Weekly Once & 1 & 12.50 \\
\hline 2 & Fortnightly Once & 5 & 62.50 \\
\hline 3 & Monthly once & 2 & 25.00 \\
\hline Total & $\mathbf{8}$ & $\mathbf{1 0 0 . 0 0}$ \\
\hline
\end{tabular}

Source- Primary data

The data shows 25 per cent of the Self-help Groups convene group meeting monthly once, 62.5 per cent once in a fortnightly and 12.5 per cent weekly once.

\section{Age of the Respondents:}

Age is the important variable that determines the physical and mental maturity of a person. The age of a person can determine her/ his productivity and working capacity. The age structure of the country also determines its prospect for development. 
Table 4.1.5: Age-Wise Classification of the Respondents

\begin{tabular}{|l|l|l|}
\hline Age Group & No. of Respondent & Percentage \\
\hline Below 25 & 2 & 2.50 \\
\hline $25-45$ & 46 & 57.50 \\
\hline $45-55$ & 27 & 33.75 \\
\hline Above 55 & 5 & 6.25 \\
\hline Total & $\mathbf{8 0}$ & $\mathbf{1 0 0 . 0 0}$ \\
\hline
\end{tabular}

Source: Field Survey

The age-wise classification of the members is given in the above table 4.1.5 it shows that among the total 80 women participants 2.5 per cent below 25 year of age, 57.5 per cent $25-45$ year of age, 33.75 per cent $45-55$ of age and 6.25 per cent above 55 years of age. The table indicates out of 80 members 73 (i.e. 91.25 per cent) are in the age of 25-55 that is considered to be effective age group for any decision-making as well as enterprise establishment.

\section{Caste Status:}

Caste is an important social variable which determines the social status of an individual in the society of India. It is a form of social stratification based on the idea of purity and population. In the rural areas, the various caste groups are stratified and grouped into various communities for the purpose of receiving the benefits of the welfare programmes of the government.

Table 4.1.6: Caste-wise Classification of Respondents

\begin{tabular}{|l|l|l|}
\hline Caste & No. of Respondents & Percentage \\
\hline SC & 10 & 12.50 \\
\hline ST & 9 & 11.25 \\
\hline OBC & 37 & 46.25 \\
\hline General & 24 & 30.00 \\
\hline Total & $\mathbf{8 0}$ & $\mathbf{1 0 0 . 0 0}$ \\
\hline
\end{tabular}

Source: Field Survey

The table 4.1.6 shows that SC and ST constitute 23.75 per cent, OBC and general caste constitute 76.25 per cent of the members. This may be due higher concentration of $\mathrm{OBC}$ and General caste representing more than 80 per cent of the population.

\section{Educational Status:}

Education is significant for the empowerment of women as it affects all the other dimensions of empowerment. Education increases knowledge and patience. The most important benefit of the SHGs is perhaps the opportunity that both illiterate and literate women can participate in the programme.

Table 4.1.7: Education-Wise Classification of Respondents

\begin{tabular}{|l|l|l|}
\hline Educational Status & No. of Respondents & Percentage \\
\hline Primary & 34 & 42.50 \\
\hline Middle & 30 & 37.50 \\
\hline Matriculate $\left(10^{\text {th }}\right)$ & 19 & 23.75 \\
\hline College & 3 & 3.50 \\
\hline Total & $\mathbf{8 0}$ & $\mathbf{1 0 0 . 0 0}$ \\
\hline
\end{tabular}

Source: Field Survey 
In the study area none of the members are illiterate this might be due to the selection of Khordha which is an urban area in the district, 42.5 per cent of the total respondents had Primary school education, 37.5 per cent are Middle school education, 23.75 per cent are Matriculate and 3.75 per cent had college education.

\section{Figure 4.1.7: Education of Respondents $3.50 \%$}

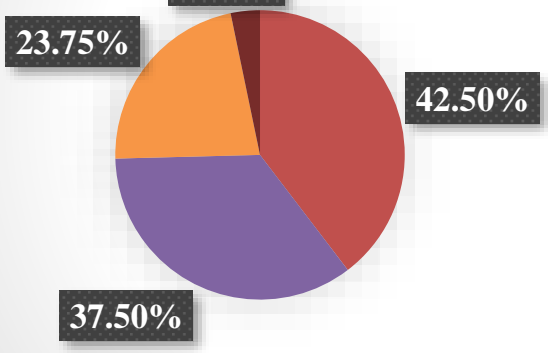

- Primary

- Middle

Matriculate (10th)

- College

\section{Marital Status:}

Marriage can be simplify defined as a universal social institution and it marks an important turning point in one's life. In Indian society, marriage is a religious duty. The following table shows the marital status of SHG members in the study area.

Table 4.1.8: Marital Status of the Respondents

\begin{tabular}{|l|l|l|}
\hline Marital Status & No. of Respondents & Percentage \\
\hline Single & 0 & 0.00 \\
\hline Married & 69 & 86.25 \\
\hline Widow & 9 & 11.25 \\
\hline Divorced & 2 & 2.50 \\
\hline Total & $\mathbf{8 0}$ & $\mathbf{1 0 0 . 0 0}$ \\
\hline
\end{tabular}

Source: Field Survey

From table 4.1.8 it is evident that 86.25 percent were married, 11.25 percent of the women were widow and only 2.5 percent of the respondents are divorced. The Self-help Group programme play a great role in economic empowerment of these women by providing them opportunity to an additional income and generate assets for the household. The program was also important to the destitute like divorced and widow women among the economically weaker sections who consider themselves as a burden to the family.

\section{Family Type and Size:}

Family is a basic social unit and the most significant agent of socialization. The family type and size of the SHG members has been shown in the following table.

Table 4.1.9: Classification of Family Type

\begin{tabular}{|l|l|l|}
\hline Family Type & No. of Respondents & Percentage \\
\hline Nuclear & 63 & 78.75 \\
\hline Joint & 17 & 21.25 \\
\hline Total & $\mathbf{8 0}$ & $\mathbf{1 0 0 . 0 0}$ \\
\hline
\end{tabular}

Source: Primary Data

Classification of Respondents based on Family Members

\begin{tabular}{|l|l|l|}
\hline Family Size & No. of Respondents & Percentage \\
\hline Less than 4 & 63 & 78.75 \\
\hline
\end{tabular}




\begin{tabular}{|l|l|l|}
\hline $4-8$ & 8 & 10.00 \\
\hline Above 8 & 9 & 11.25 \\
\hline Total & $\mathbf{8 0}$ & $\mathbf{1 0 0 . 0 0}$ \\
\hline
\end{tabular}

Source: Primary data

This indicate the type of the family of Self-help Group members, About 78.75 per cent have nuclear family with a family size less than 4 and 21.25 per cent joint family the size of the family members are more than 4 . There is steep emergence of nuclear family and substantial decrease of the age old joint family system in the urbanized Khordha area of Odisha.

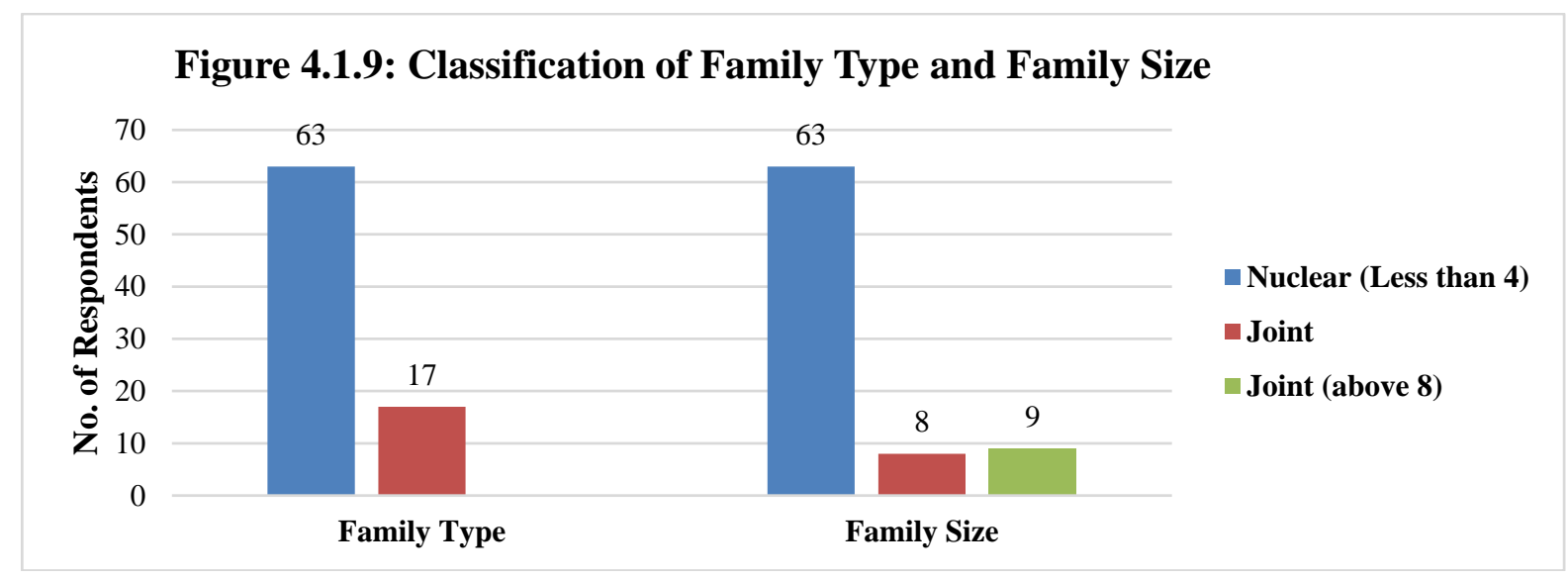

\section{Occupational Distribution:}

The Government of India realized that if different employment opportunities can be created, along with sufficient training and refreshers courses for capacity development, the poor could be linked to the mainstream economy which would ultimately bring them out of poverty. With a view to employment generation, Indian government initiated the SGSY (Swarnajayanti Gram Swarozgar Yojana) scheme to provide microfinance services and renders, training and skills development services with the help of SHG approach.

Table 4.1.10: Occupation-Wise Classification of Respondents

\begin{tabular}{|l|l|l|}
\hline Occupational Status & No. of Respondents & Percentage \\
\hline Housewife & 48 & 60.00 \\
\hline Small Business & 16 & 20.00 \\
\hline Tailoring & 12 & 15.00 \\
\hline Govt. job (contractual) & 4 & 5.00 \\
\hline Total & $\mathbf{8 0}$ & $\mathbf{1 0 0 . 0 0}$ \\
\hline
\end{tabular}

Source: Field Survey

It is clearly evident from the table 4.1.10 that before joining the SHG most of the members were housewives (60.00 per cent), small business (20.00 per cent), tailoring work (15/00 per cent) and govt. job (5.00 per cent).

\subsection{Contribution of SHG on Additional Employment generation of Women in the Household}

One of the major reasons for poverty in the society is unemployment in rural India, women are engaged in household work and as a result they able to get enough employment opportunities to sustain better living for the family. It is necessitated for the women in the family to create employment opportunities through group action by forming Self-help Groups for the economic upliftment of themselves as well as their families. Employment provides purchasing power to the person who are employed. If more of the family members are employed more will be the purchasing power of family. In the present study the sample respondents are getting additional employment opportunities by joining different production activities in SHGs and also marketing of products to the customers. Employment generated through group action/ intervention of Self-help Groups is shown in the following table.

Table 4.2: Contribution of SHG on Employment generation

\begin{tabular}{|l|l|l|l|}
\hline Sl. no. & Employment generation & No. of respondents & Percentage \\
\hline
\end{tabular}




\begin{tabular}{|l|l|l|l|}
\hline 1 & $5-10$ Days & 26 & 32.50 \\
\hline 2 & $10-15$ Days & 30 & 37.50 \\
\hline 3 & $15-20$ Days & 17 & 21.25 \\
\hline 4 & Above 20 Days & 7 & 8.75 \\
\hline Total & $\mathbf{8 0}$ & $\mathbf{1 0 0 . 0 0}$ \\
\hline
\end{tabular}

Source- Primary data

It is clearly evident from the Table 4.2 that 32.50 per cent got employment between 5-10 days, 37.50 per cent got employment between 10-15 days, 21.25 per cent got employment between 15-20 days and 8.75 per cent got employment between above 20 days. It is inferred from the table that majority of the SHG members i.e. 37.50 per cent of the respondents have got additional employment between 10-15 days per month. The additional employment increases the individual's income as well as family income there by enhances standard of living of the family.

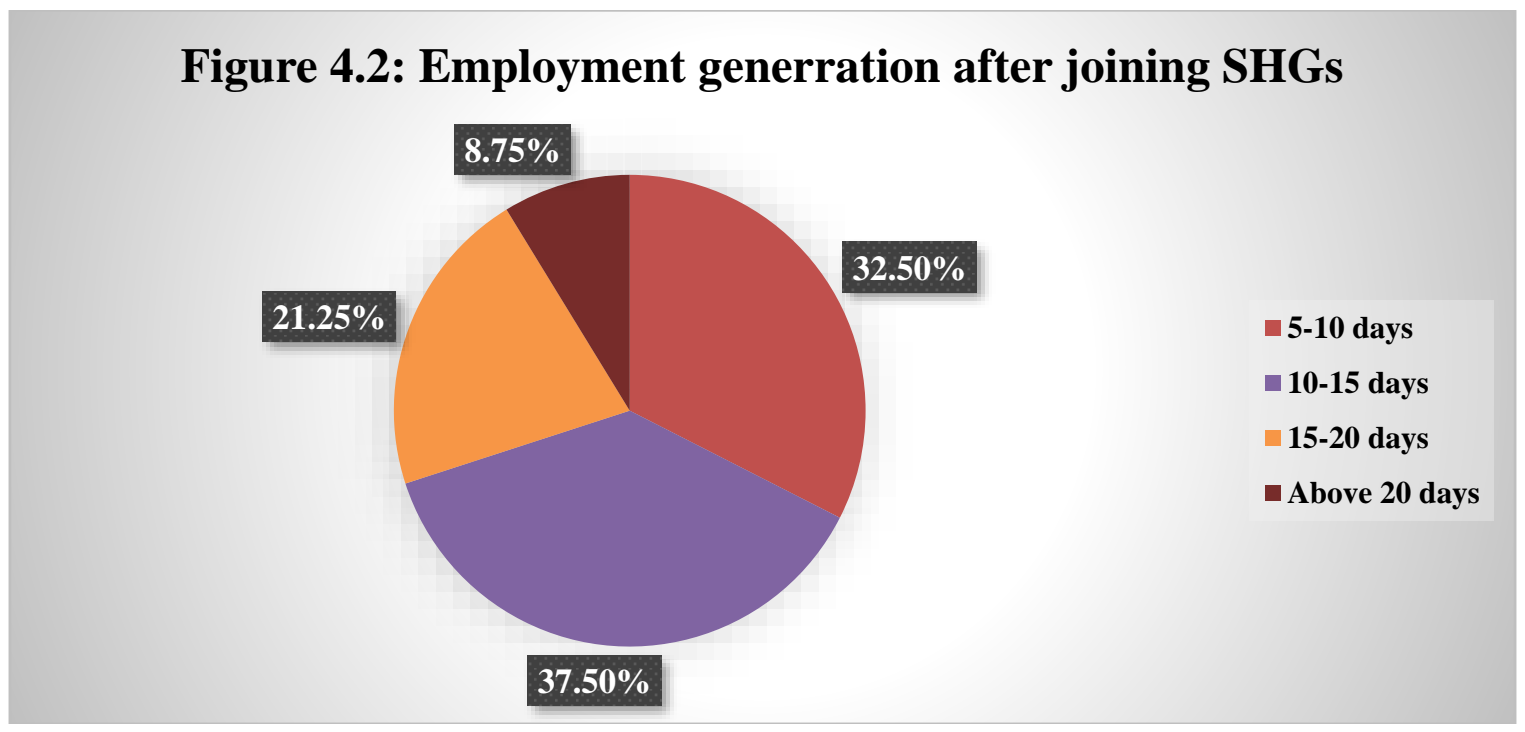

\section{CONCLUSION}

The Self Help Group programme has created tremendous impact on the livelihood of rural women in particular. The present study not only demonstrates positive impact of self help groups on several socio-economic dimensions of rural women, it also strongly endorses the findings of earlier studies. Majority of SHG members were able to get additional employment under different activities by SHG finance. Additional employment also increased their income level. The income level increased significantly after they took part in group activities. The increase in income is also distributed uniformly among all the members. The SHGs also help in improving standard of living thereby making it possible for rural household to spend more in education for children and family health. The study has found that SHGs have served the cause of women empowerment and socio-economic betterment of rural poor women.

\section{REFERENCES}

[1] Atibudhi H. N., Pal Subhadip, 2013, "women empowerment and decision making in agriculture through self-help group- an economic analysis in Burdwan district, West Bengal”, www.krishikosh.com, 1-189
[2] Ariz Ahamed M., 1999, Women empowerment: self-help Groups. Kurukshetra 47(4), 20.

[3] Banerjee (Chatterjee), T., 2009, "Economic Impact of Self Help Groups - a case study". Journal of Rural Development, 20(4), 451467.

[4] Bansode, Mahadevrao smita, 2007, impact of SHGs on Socio-economic development of their members, www.krishikosh .com

[5] Baro, P. K. and Sarania, R., 2014, "Employment and Educational Status: Challenges of Women Empowerment in India", Pratidhwani-The Echo, VolII, Issue-IV, PP.49-56.

[6] Basargekar, P., 2009, "How Empowering is Micro Entrepreneurship DevAeloped through Microfinance?”, Asia-Pacific Business Review, Vol-V, No-1, pp.67-76

\section{AUTHORS}

First Author - Miss Subhashree Mishra, PG Scholar, Deartment of Economics, Institute of Agricultural Sciences, SOADU Second Author - Dr. H. N. Atibudhi, HOD, Department of Economics, Faculty of Institute of Agricultural Sciences, SOADU 
International Journal of Scientific and Research Publications, Volume 10, Issue 11, November 2020

This publication is licensed under Creative Commons Attribution CC BY. 